\title{
Progressive loss of vision caused by asymptomatic pituitary macroadenoma: role of OCT
}

This article was published in the following Dove Press journal:

International Medical Case Reports Journal

16 September 2016

Number of times this article has been viewed

\section{Víctor Manuel \\ Asensio-Sánchez \\ Javier Foncubierta \\ Ophthalmology Department, Clinical University Hospital of Valladolid, \\ Valladolid, Spain}

Introduction: Most pituitary adenomas are clinically inactive. In patients with long-standing compression of the optic chiasm, ganglion cells may undergo axonal degeneration. Spectral domain optical coherence tomography (SD-OCT) is able to identify retinal nerve fiber layer (RNFL) and ganglion cell loss in the retina. We present a case in which SD-OCT was used to diagnose an asymptomatic pituitary macroadenoma.

Clinical case: A 48-year-old female presented with progressive vision loss in both eyes. SDOCT identified atrophy of the ganglion cell and nerve layers, with preservation of outer layers bilaterally. Magnetic resonance imaging of the brain showed a pituitary macroadenoma. The pathological diagnosis was nonfunctioning adenoma.

Discussion: As macroadenomas enlarge, they can induce uncrossed axon loss, resulting in nasal field defects and reduced visual acuity. In these cases, there is atrophy of the nasal and temporal portions of the optic disc, thus occupying a horizontal band across the disc. SD-OCT is able to identify RNFL loss in eyes with band atrophy of the optic nerve, which correlates with visual field defects found in perimetry. SD-OCT is a useful tool to assess the structural and functional damage of ganglion cells. In our case the SD-OCT demonstrated a symmetrical loss of the RNFL and the ganglion cell layer in both eyes, indicating important optic nerve damage.

Keywords: OCT, pituitary, adenoma, RNFL, ganglion cell layer

\section{Introduction}

Pituitary adenoma is the most common cause of the chiasmal syndrome. ${ }^{1}$ The tumor is classified based on size as microadenoma, smaller than $10 \mathrm{~mm}$, or as macroadenoma when it exceeds $10 \mathrm{~mm}$ in diameter. ${ }^{2}$ Some tumors secrete one or more hormones in excess, so-called secretory pituitary adenomas, but most are clinically inactive. ${ }^{3}$ Classically, the nonsecretory tumors present with vision loss, ${ }^{4}$ whereas patients with secretory tumors are usually referred to ophthalmologists for evaluation due to hormonal imbalances that affect bodily functions. ${ }^{5}$ In patients with long-standing compression of the optic chiasm, ganglion cells may undergo axonal degeneration ${ }^{4}$. Such axonal loss can sometimes be observed in the optic disc and retina. Optical coherence tomography (OCT) is able to identify retinal nerve fiber layer (RNFL) and ganglion cell loss in retina. ${ }^{6,7}$ We present a case in which the OCT (3D OCT-2000 Spectral Domain OCT, Topcon Corporation, Tokyo, Japan ) was used to diagnose an asymptomatic pituitary macroadenoma.

The authors adhere to the International Standards developed in the $2^{\text {nd }}$ Conference on Research Integrity in Singapore (2010), while performing this study. The patient agreed to have their case published, and all information presented is non-identifiable. ${ }^{8}$
Calle Librerí,

Tel +34 600075585

Email javi_foncu@hotmail.com 


\section{Clinical case}

A 48-year-old, Caucasian female presented with progressive vision loss in both eyes for several months. Her past ocular, medical, and family history was non-contributory with no fatigue, loss of libido, no mood change, and no weight change. On examination, best-corrected visual acuity was hand motion in the right eye and $2 / 3$ in the left eye. The anterior segment and intraocular pressure examination were normal in each eye. The macula and peripheral retinal fluorescein angiography were normal in both eyes. Spectral domain optical coherence tomography (SD-OCT) demonstrated diffuse atrophy of the ganglion cell and nerve layers, with preservation of outer layers bilaterally (Figure 1 and Figure 2). Magnetic resonance imaging of the brain was performed and a pituitary macroadenoma with suprasellar extension was observed (Figure 3). Resection was performed and the pathological diagnosis was nonfunctioning adenoma. Despite the surgery, the vision did not improve.

\section{Discussion}

Pituitary adenomas are common benign tumors of the pituitary gland that account for $12 \%$ of all intracranial tumors. ${ }^{9}$ People can develop pituitary adenomas at any age. Most pituitary adenomas are in the anterior lobe of the pituitary gland. Some adenomas secrete hormones in excess. Of the secretory tumors, the most common are prolactinomas. ${ }^{5}$

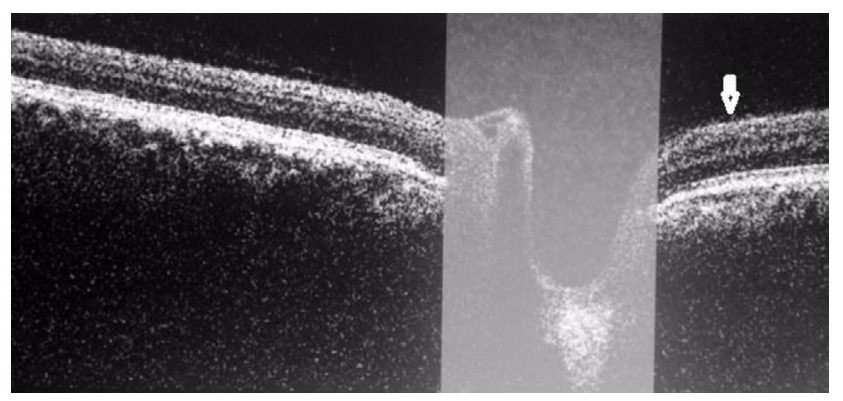

Figure I Spectral domain coherence tomography identifies symmetric retinal nerve fiber layer and ganglion layer loss in the left eye (arrow).

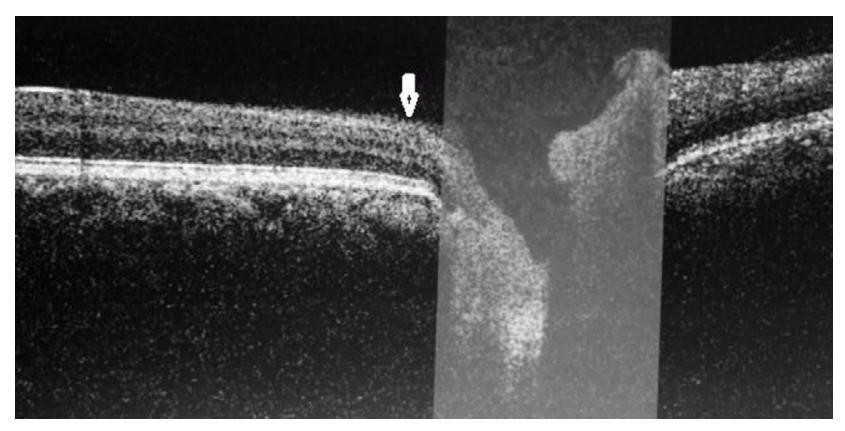

Figure 2 Spectral domain coherence tomography identifies symmetric retinal nerve fiber layer and ganglion layer loss in the right eye (arrow).
They may be relatively small when detected. The most common symptoms include headaches, menstrual changes in females, sexual dysfunction in males, vision problems, and behavioral changes. ${ }^{5}$ Diagnostic imaging may include a high-resolution, T1 weighted, gadolinium enhanced magnetic resonance imaging. ${ }^{10}$ Other secretory tumors may secrete corticotropin, growth hormone, gonadotropins, or thyroidstimulating hormone. ${ }^{11}$ Adenomas remain confined to the pituitary gland, but when a pituitary adenoma is $\geq 10 \mathrm{~mm}$ it is called a macroadenoma. Macroadenomas can compress the rest of the pituitary gland and surrounding structures, such as the crossing retinal ganglion cell axons in the optic chiasm, resulting in bitemporal visual field loss. ${ }^{4}$ As the tumor enlarges, it has been shown to induce uncrossed axons loss, resulting in nasal field defects and reduced visual acuity. In these cases, there is atrophy of the nasal and temporal portions of the optic disc with relative sparing of the superior and inferior parts where the majority of temporal fibers enter. The optic atrophy occupies a horizontal band across the disc, called bowtie or band atrophy. ${ }^{12,13}$ OCT is a noninvasive technique that allows cross-sectional imaging of the retina and quantifies the thickness of the RNFL around the optic nerve head. A number of studies have demonstrated that OCT is able to identify RNFL loss in eyes with band atrophy of the optic nerve. ${ }^{6,7}$ The degree of RNFL thickness reduction has been shown to correlate with that of visual field defects using

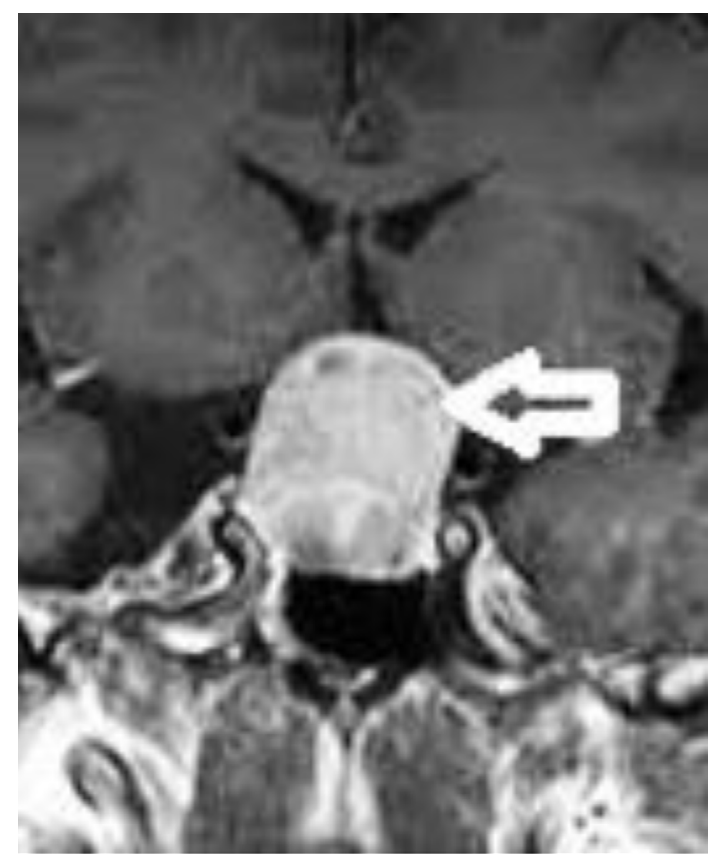

Figure 3 Coronal view, post-contrast TI brain magnetic resonance imaging, showing a pituitary macroadenoma with compression of the optic chiasm (arrow). 
Goldmann perimetry ${ }^{4}$ and automated static perimetry. ${ }^{14,15}$ This fact gives OCT prognostic value regarding the visual outcome, as demonstrated in different studies. ${ }^{16,17} \mathrm{OCT}$ is a useful tool to assess the structural and functional damage of ganglion cells, objectively and quantitatively. ${ }^{4}$ In our case the SD-OCT demonstrates a symmetrical loss of the RNFL and the ganglion cell layer in both eyes, indicating important optic nerve damage.

\section{Conclusion}

SD-OCT can help in the diagnosis of adenomas in equivocal situations in which there is only subtle optic nerve pallor in the setting of nonspecific visual complaints or visual field defects, or when patients are referred to screen for subclinical compressive optic neuropathies.

\section{Disclosure}

The authors report no conflicts of interest in this work.

\section{References}

1. Foroozan, R. Chiasmal syndromes. Curr Opin Ophthalmol. 2003;14(6): 325-331.

2. Ezzat S, Asa SL, Couldwell WT, et al. The prevalence of pituitary adenomas. Cancer. 2004;101(3):613-619.

3. Fernandez-Balsells MM, Murad MH, Barwise A, et al. Natural history of nonfunctioning pituitary adenomas and incidentalomas: a systematic review and metaanalysis. J Clin Endocrinol Metab. 2011;96(4): 905-912.

4. Abouaf L, Vighetto A, Lebas M. Neuro-ophthalmologic exploration in non-functioning pituitary adenoma. Ann Endocrinol (Paris). 2015;76(3):210-219.

5. Cooper O, Melmed S. Subclinical hyperfunctioning pituitary adenomas: the silent tumors. Best Pract Res Clin Endocrinol Metab. 2012; 26(4):447-460.
6. Kanamori A, Nakamura M, Matsui N et al. Optical coherence tomography detects characteristic retinal nerve fiber layer thickness corresponding to band atrophy of the optic disc. Ophthalmology. 2004; 111:2278-2283.

7. Monteiro MLR, Leal BC, Rosa AAM, Bronstein MD. Optical coherence tomography analysis of axonal loss in band atrophy of the optic nerve. Br J Ophthalmol. 2004;88:896-889.

8. Wager E, Kleinert S. Responsible research publication: international standards for authors. A position statement developed at the 2nd World Conference on Research Integrity, Singapore, July 22-24, 2010. In Mayer T, Steneck N (eds) Promoting Research Integrity in a Global Environment. Imperial College Press / World Scientific Publishing, Singapore. 2011.

9. Musluman AM, Cansever T, Yilmaz A et al. Surgical results of large and giant pituitary adenomas with special consideration of ophthalmologic outcomes. World Neurosurg. 2011;76:141-148.

10. Hall WA, Luciano MG, Doppman JL, Patronas NJ, Oldfield EH. Pituitary magnetic resonance imaging in normal human volunteers: occult adenomas in the general population. Ann Intern Med. 1994; 120(10):817-820.

11. Dworakowska D, Grossman AB. The pathophysiology of pituitary adenomas. Best Pract Res Clin Endocrinol Metab. 2009;23(5):525-541.

12. Johansson $\mathrm{C}$ and Lindblom B. The role of optical coherence tomography in the detection of pituitary adenoma. Acta Ophthalmol. 2009; 87:776-779.

13. Unsold R and Hoyt WF. Band atrophy of the optic nerve. Arch Ophthalmol. 1980;98:1637-1638.

14. Jacob M, Raverot G, Jouanneau E, et al. Predicting visual outcome after treatment of pituitary adenomas with optical coherence tomography. Am J Ophthalmol. 2009;147(1):64-70.

15. Danesh-Meyer HV, Carroll SC, Foroozan R, et al. Relationship between retinal nerve fiber layer and visual field sensitivity as measured by optical coherence tomography in chiasmal compression. Invest Ophthalmol Vis Sci. 2006;48:4827-4835.

16. Saxena R, Gopalakrishnan K, Singh D, Mahapatra AK, Menon V. Retinal nerve fiber layer changes: a predictor of visual function recovery in pituitary adenomas. Indian J Med Specialities. 2015;6(4): 141-145.

17. Moon CH, Hwang SC, Kim BT, Ohn YH, Park TK. Visual prognostic value of optical coherence tomography and photopic negative response in chiasmal compression. Invest Ophthalmol Vis Sci. 2011;52(11) 8527-8533.
International Medical Case Reports Journal

\section{Publish your work in this journal}

The International Medical Case Reports Journal is an international, peer-reviewed open-access journal publishing original case reports from all medical specialties. Previously unpublished medical posters are also accepted relating to any area of clinical or preclinical science. Submissions should not normally exceed 2,000 words or
Submit your manuscript here: https://www.dovepress.com/international-medical-case-reports-journ

4 published pages including figures, diagrams and references. The manuscript management system is completely online and includes a very quick and fair peer-review system, which is all easy to use. Visit http://www.dovepress.com/testimonials.php to read real quotes from published authors. 